\title{
K OTÁZCE MARKETINGU ZÁKLADNÍCH UMĚLECKÝCH ŠKOL
}

Současná česká společnost je $\mathrm{v}$ ekonomické rovině charakterizována dynamikou svého rozvoje, který se v podmínkách tržního hospodářství samozřejmě největší měrou dotýká subjektů komerčního charakteru. Chtějí-li obhájit svou pozici na relevantních trzích, jsou nuceny se dynamice společnosti a vývoji jejích očekávání přizpůsobovat či jej dokonce předcházet. Je známým faktem, že na klasických trzích statků a služeb, poskytovaných na komerční bázi, vzniká produkt (zboží, služba) jako reakce na poptávku nebo v predikci př́ístího očekávání zákazníků.

Pokud tvrdíme, že dynamice společnosti se musí v zájmu zachování své existence přizpůsobit zejména komerční subjekty, je nasnadě otázka, jak je tomu $\mathrm{v}$ př́padě neziskového sektoru (pozn. $\mathrm{v}$ tomto př́ípadě chápeme neziskový sektor podle Pestoffova vymezení ${ }^{1}$, tedy jako zastřešující pojem pro množinu soukromých i veřejných neziskových organizací). Neziskový sektor je tvořen organizacemi, které za účel své existence nemají vytváření zisku, což je odlišuje od komerčních subjektů; nový občanský zákoník, tedy zákon č. 89/2012 Sb. definuje neziskovou organizaci jako tzv. veřejně prospěšnou právnickou osobu, ,jejímž posláním je prisspívat v souladu se zakladatelským právním jednáním vlastní činností k dosahováni obecného blaha“. ${ }^{2}$ Smyslem fungování neziskových organizací je tedy, v obecné rovině řečeno, vytváření prospěchu či hodnot prospěšných celé společnosti, př́padně jejich udržování. Tyto hodnoty se týkají všech oblastí působení neziskových organizací, tedy zejména kulturního dědictví, životního prostředí, sportu, lidských práv, vzdělávání, bezpečnosti, zdravotnictví atd. Je nasnadě ptát se, zda takto charakterizované statky a služby, resp. produkty, jejichž

1 PESTOFF, Victor A. Reforming Social Services in Central Eastern Europe and Eleven Nation Overview. In: Sborník CRYF, Krakov 1995.

2 Ministerstvo spravedlnosti ČR. Zákony a stanoviska - Texty zákonů: Nový občanský zákoník [online]. 2013 - 2015 [cit. 2015-07-01]. Dostupné z: <http://obcanskyzakonik.justice.cz/ texty-zakonu/>. 
původcem je neziskový sektor, musí respektovat dynamiku rozvoje společnosti, př́padně jak funguje vztah nabídky a poptávky na jejich relevantních trzích.

\section{Veřejná objednávka}

Neziskový sektor v podstatě produkuje služby na tzv. veřejnou (společenskou) objednávku. Míněna je tím shoda např́íc společností na určitých hodnotách, jež je třeba chránit a rozvíjet a kvalitách, které je nezbytné udržovat či vytvářet. Mohlo by se tedy zdát, že se jedná o entity, které se naprríč staletími př́liš neproměnily: svoboda, bezpečnost, zdraví, úcta k dílu přechozích generací, ochrana životního prostředí, uměleckých hodnot a další. V posledním století však pocitujeme dosud nejsilnější krizi hodnot a rozvolnění společenského řádu. Jaké hodnoty by tedy měl neziskový sektor chránit a zprostředkovávat? Ty, které byly platné před sto lety (kdy byl svět, řečeno reklamním jazykem, ještě v pořádku)? Nebo hodnoty, které respektuje současná společnost? A kdo by je měl v tom př́ípadě definovat?

Na původní otázku lze tedy odpovědět: Ano, neziskové organizace se musí přizpo̊sobit dynamice dnešní doby, ale nejprve je třeba ujasnit si smysl jejich fungování a hodnoty, které mají zprostředkovávat - souhrnně lze hovořit o poslání instituce.. Legendární americký autor Peter Drucker tvrdil v této souvislosti, že „poslání je smyslem existence neziskových organizaci “ a že „,má vždy dlouhodobou platnost". ${ }^{3}$

Základní umělecké školy jsou dobrým př́íkladem institucí, jejichž poslání není části veřejnosti prŕliš jasné, resp. nejsou př́lišs komunikovány a v tradičních debatách o povaze národního školství jsou obvykle vynechávány. Nejasnou otázkou je zde tím pádem i již zmiňovaná veřejná objednávka - jak zní v př́ípadě základních uměleckých škol? Jako objednávka na učiliště poskytující první stupeň uměleckého vzdělání budoucím profesionálním umělcům? Objednávka na místo pro trávení volného času hrou na umění? Na školské zařízení vychovávající kultivovaného jedince? Otázek se nabízí mnohem více. Např́íklad: jaké umění se na základních uměleckých školách dnes vlastně vyučuje? Klasické, tedy pro nemálo žáků mrtvé, avšak s potenciálem rozššřit jejich obzory? Nebo současné, živé, ovšem někdy diskutabilní? A jakému umění by se vlastně vyučovat mělo? A v neposlední řadě - jakým způsobem? Jsou např́íklad v oblasti hudby př́nosnější přehrávky, nebo improvizace?

V možnostech tohoto př́spěvku není hledat odpovědi na tyto otázky vhodné spiše pro odbornou diskusi, předmětem jeho zájmu jsou konkrétní veřejné neziskové organizace, základní umělecké školy. Ty můžeme v intencích shora popsaného označit za veřejné neziskové organizace jen tehdy, hovoříme-li o takových základních uměleckých školách, které nejsou zřizovány soukromoprávním subjektem (at' už fyzickou či právnickou osobou). Smyslem tohoto př́spěvku je pak

3 DRUCKER, Peter. Řizení neziskových organizací: praxe a principy. 1. vyd. Praha: MANAGEMENT PRESS, 1994, s. 48. 
zejména poukázat na význam marketingu pro základní umělecké školy jako nástroje, který těmto institucím umožní odpovídat na tyto otázky nejen veřejnosti, ale mnohdy i (především) sobě.

Autor příspěvku se v od roku 2009 průběžně věnuje výzkumu v oblasti základních uměleckých škol, prričemž se zaměřuje zejména na úlohu marketingu v jejich fungování a stupeň aplikace tohoto nástroje řizení do základního uměleckého školství jako celku. Individuálně pak studuje efekty marketingu aplikovaného do praxe základních uměleckých škol tam, kde již k jeho uplatnění došlo. Lze konstatovat, že pojednávanému tématu se sice $\mathrm{v}$ posledních letech dostává príležitostně pozornosti v absolventských pracích studentů vysokých škol se zaměřením na školství či uměnovědné obory, ovšem problematika zatím stojí spíše stranou seriózního vědeckého zájmu a zkoumání.

\section{Základní umělecké školy}

Současná podoba základního uměleckého školství u nás vychází ze staleté tradice uměleckého (a přibližně dvě stě let vlastně výhradně hudebního) vzdělávání v českých zemích. Vůbec nejstarší dokumenty dokladují existenci hudebního vzdělávání již v sedmnáctém století. $\mathrm{V}$ dalším století je dokumentováno působení kvalifikovaných kantorů a v devatenáctém století již vznikají městské hudební školy, které lze považovat za základní kameny často skloňované tradice organizovaného hudebního vzdělávání u nás. První uměleckou školou na našem území byla Kreslírská akademie (dnes Akademie výtvarných umění), která začala vyučovat $\mathrm{r}$. $1800 .{ }^{4} \mathrm{~V}$ období růstu československého státu ve dvacátých a částečně i třicátých letech 20. století dostala otázka uměleckého vzdělávání silný podtext národního uvědomění a počet hudebních škol rostl; o významu přikládaném hudebním školám svědčí i to, že nově byly pod dohledem školní inspekce. Po druhé světové válce byl v legislativě ukotven jednotný typ základních hudebních škol, které se však v šedesátých letech proměnily v tak zvané lidové školy umění (odtud jejich pozdější hovorové označení „lidušky“). Došlo také ke změně ve struktuře vyučovaných oborů: $\mathrm{k}$ dosud jediném hudebnímu oboru přibyly i obory taneční, výtvarný a literárně dramatický. $V$ sedmdesátých letech lidové školy umění ztratily prestiž i roli ve vzdělávací soustavě - byly překvalifikovány na pouhá školská zařízení. ${ }^{5}$ To se změnilo až v roce 1990 , kdy novela školského zákona těmto zařízením vrátila statut školy, jejich název změnila na základní umělecké školy a opět je zařadila do národní soustavy navazujícího uměleckého vzdělávání.

„Základní umělecké školy umožňuji podchytit a vzdělávat většinu nadaných i výrazně talentovaných jedinců a odborně je připravit na neprofesionální uměleckou

$4 \quad$ PRŮCHA, Jan. Pedagogická encyklopedie. 1. vyd. Praha: Portál, 2009, s. 98.

5 Rámcový vzdělávací program pro základní umělecké vzdělávání. 1. vydání. [online]. Praha: Výzkumný ústav pedagogický, 2010. 63 s. [cit. 2015-07-01]. Dostupné z WWW: <http:// www.vuppraha.cz/wp-content/uploads/2009/12/PRM_RVPZUV_NAWEB.pdf>, s. 8. 
činnost, popřípadě na studium ve středních a vysokých školách uměleckého nebo pedagogického zaměreni a na studium v konzervatořich. Základni umělecké vzděláváni poskytuje základy vzdělání vjednotlivých uměleckých oborech - hudebnim, tanečním, výtvarném a dramatickém. Je nedilnou součástí provázaného systému uměleckého vzděláváni v ČR", 6 uvádí Rámcový vzdělávací program pro základní umělecké vzdělávání.

\section{VYSOKÉ ŠKOLY UMĚLECKÉ (PEDAGOGICKÉ)}

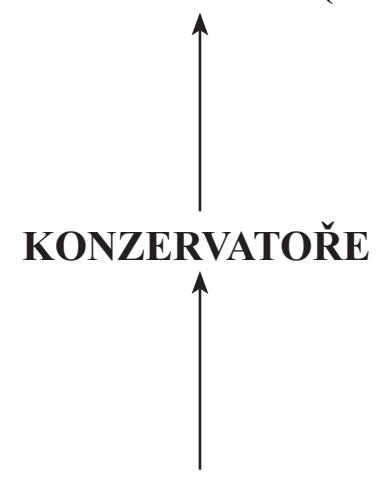

\section{ZÁKLADNÍ UMĚLECKÉ ŠKOLY}

Obr. 1. Systém uměleckého vzdělávání ČR (Zdroj: vlastní vypracování dle zákona č. 561/2004 Sb., o předškolním, základním, středním, vyšším odborném a jiném vzdělávání).

V intencích českého systému uměleckého vzdělávání sice základní umělecké školy neposkytují žádný stupeň vzdělání, nicméně mezi odbornou veřejností panuje shoda na tom, že obsažení a zvládnutí základů vzdělání v uměleckých oborech je nezbytným východiskem pro absolvování dalších stupňů.

Základní umělecké vzdělávání má formu dlouhodobého, systematického a komplexního studia. Zásadním př́nosem základního uměleckého vzdělávání je jeho př́spěvek k rozvoji a kultivaci uměleckého nadání všech zájemců, jejichž předpoklady ke studiu dosáhnou potřebné míry. Zároveň základní umělecké vzdělávání, potažmo základní umělecké školství plní roli rozsáhlé platformy pro systematické vyhledávání umělecky talentovaných jedinců. ${ }^{7}$

V souladu s požadavky školského zákona (Zákon č. 561/2004 Sb., o předškolním, základním, středním, vyšším odborném a jiném vzdělávání) byl pro realizaci základního uměleckého vzdělávání vydán Rámcový vzdělávací program pro umělecké obory základního uměleckého vzdělávání, který řeší otázky vzdělávacího zaměření či rámcové učební plány pro jednotlivé obory základního uměleckého vzdělávání.

6 Rámcový vzdělávací program pro základní umělecké vzdělávání. 1. vydání. [online]. Praha: Výzkumný ústav pedagogický, 2010. 63 s. [cit. 2015-07-01]. Dostupné z WWW: <http:// www.vuppraha.cz/wp-content/uploads/2009/12/PRM_RVPZUV_NAWEB.pdf>, s. 8. 


\section{Škola jako tržní subjekt}

Pokud neziskový a s ním i veřejný sektor posuzujeme optikou managementu, zdálo by se, že „v jistém smyslu, novou naději“ pro chápáni škol jako více méně běžných organizaci je reforma veřejného sektoru postupně realizovaná v různých zemich rozvinutého světa. Tzv. nové ř́zení veřejného sektoru (New Public Management) lze ve stručnosti charakterizovat záměrem uplatňovat tržní logiku i v prostředí, které se tradičně za tržní nepovažuje. Veřejný sektor je nahližen jako quasi-trh spravovaný politickými silami. Uplatňované strategie obvykle akcentuji inovace, nové technologie, tlak na výkon a manažerskou akontabilitu" ". Veřejný sektor je přitom považován za prostor s dominancí tržního mechanismu, kde se vyskytují stejnorodé subjekty. ${ }^{9}$ Vzdělávací instituce jako veřejné neziskové organizace tedy $\mathrm{v}$ tomto pojetí netvoří výjimku - od ostatních organizací veřejného sektoru se neliší a lze odvodit, že je možné spravovat je a řídit shodně jako jiné organizace. Mluvíme přitom samozřejmě v principiální rovině a individuální oborové odlišnosti ponecháváme stranou.

Školské instituce lze tedy charakterizovat jako subjekty na trhu vzdělávacích služeb. Ten přitom „můžeme chápat jako určitou oblast reality společnos$t i$, ve které dochází $k$ výměně činností mezi jednotlivými ekonomickými subjekty (škola, domácnost, stát) prostřednictvím směny" ${ }^{10}{ }^{10} \mathrm{Klíčovým} \mathrm{(a} \mathrm{možná} \mathrm{v} \mathrm{inten-}$ cích klasického chápání školství i překvapivým) poznatkem tedy je, že škola je součástí systému tržní směny, tržním subjektem. Jako taková tedy podléhá všem zákonitostem tržních mechanismů a je vystavena konkurenci ostatních tržních subjektů, které nabízejí stejné nebo obdobné služby pro stejnou cílovou skupinu př́jemců těchto služeb.

Instituce veřejného školství se však dosud potýkají s ne zcela dostatečnou akceptací tržních mechanismů a tím související aplikací procesů managementu. To vynikne zejména v současné situaci, kdy je veřejné školství vystaveno konkurenci ze strany soukromých institucí na všech svých stupních. Soukromé školské subjekty sice shodně jako ty veřejné reguluje př́slušná legislativa, avšak na rozdíl od nich nepodléhají předsudkům vůči moderním trendům v oblasti managementu škol.

\section{Marketing do škol}

Největším handicapem, který veřejné školy mají ve srovnání se soukromými, zůstává i nadále neschopnost marketingově pojmout samy sebe jako produkt.

\footnotetext{
$8 \quad$ POL, Milan. Škola v proměnách. 1. vyd. Brno: Masarykova univerzita, 2007, s. 13.

9 Ibid, s. 13.

10 JAKUBÍKOVÁ, Dagmar. Aplikace marketingu ve školství. 1. vyd. Plzeň: Vydavatelství Západočeské univerzity, 1998, s. 39.
} 
Proč je tomu tak? Ze zkoumání ${ }^{11}$ a praktických poznatků autora tohoto prríspěvku lze usuzovat, že problémy jsou především dva: ekonomický a personální.

Ekonomický problém spočívá především v zažitém mýtu, že marketing ve školství je plýtváním veřejnými prostředky, protože spotřeba naprosté většiny služeb produkovaných veřejným sektorem je vynucená a jejich př́ijemce se proto nechová jako klasický zákazník. Naproti tomu však lze konstatovat, že „tlak na výhodné, účinné a hospodárné využivání veřejných zdrojů zpưsobil, že se marketingu věnuje den ze dne větší pozornost ${ }^{\text {" }} .^{12}$ Je to tedy především požadavek efektivnosti, který přináší potřebu marketingu do veřejného sektoru - setkáváme se s vnímáním občana coby klienta, jehož potřeby je třeba poznat a uspokojit s maximální efektivností při využití veřejných zdrojů. Analogicky tak nacházíme při aplikaci marketingu ve školství konstrukt žáka coby klienta, ${ }^{13}$ př́ípadně spotřebitele poskytovaných služeb (tím však je spíše jeho rodič, nebot' více on, než samotný žák, rozhoduje o účasti svého dítěte v uměleckém vzdělávání - v podstatě jde o rozdíl mezi odběratelem, který službu nakupuje /rodič/ a jejím konečným př́ijemcem /žák/). Jediným ekonomickým problémem, který tak může stát v cestě aplikaci marketingu ve školství, jsou mantinely rozpočtu školy, tedy omezené finanční zdroje. Paradoxně stimulem pro uplatňování marketingu v soukromých školách jsou také omezené finanční zdroje, konkrétně absence dotací zřizovatele, jimiž disponují veřejné ZUŠ. Jsme zde tak svědky toho, že finanční omezení se ve veřejném školství obvykle projevuje eliminací marketingu (absence peněz navíc), zatímco v soukromém školství jeho aplikací (absence ,jistých peněz").

Druhým problémem je pak rovina personální. V podstatě jde o náhled, který na vhodnost aplikace marketingu ve školství chová ředitel školy (manažer). Je třeba dodat, že se jedná obvykle o generační záležitost. Libuše Kolínková nabízí ještě druhý úhel pohledu na roli ředitele školy v procesu aplikace marketingu: „Nejdi̊ležitějši je ale skutečnost, že vedoucí pracovnici škol nejsou většinou vzdělani v oboru marketingových komunikací a na najímání profesionálních marketingových odbornikư také mnohdy nejsou pripraveni. Vzdálená skutečnosti je predstava, že by většina škol zaměstnávala vlastního marketingového odborníka. Marketingové komunikaci se tak na školách věnuji většinou sami ředitelé, kteři ale v rámci všech svých úkolù nemaji tolik času. " 14

Jaké je řešení obou popsaných problémů? Personální problém může pomoct vyřešit systém dalšího vzdělávání pedagogických pracovníků, osvětová činnost v tomto směru a samozřejmě také přirozená generační výměna. Řešení ekonomického problému je pak provázáno s personálním - manažer, který pochopí

11 ŠEBA, Michal. Aplikace marketingové komunikace v základním uměleckém školství. Brno, 2010. Diplomová práce. Masarykova univerzita. 83 s.

12 JAKUBÍKOVÁ, Dagmar. Aplikace marketingu ve školství. 1. vyd. Plzeň: Vydavatelství Západočeské univerzity, 1998, s. 31.

13 Ibid., s. 41.

14 KOLÍNKOVÁ, Libuše. Ředitel marketérem: aneb Marketing v českém školství. Strategie.cz [online]. 26. května 2008, [cit. 2015-07-01]. Dostupný z WWW: <http://www.strategie.cz/ scripts/detail.php?id=360688>. 
potřebnost aplikace marketingu, by měl dokázat $\mathrm{k}$ tomu účelu najít či vytvořit prostředky, at' již opatřením v rozpočtu školy nebo získáním prostředků od jiných subjektů - dárců, sponzorů, nadací atd. To vše při vědomí známé skutečnosti, že investice do marketingu, promítnuto na časovou osu, se i v neziskové organizaci několikanásobně vrací. Jak připomíná neziskovým organizacím Peter Drucker, „naším úkolem je investovat zdroje, kterými jsme byli obdařeni - at’ už jde o lidi, nebo penize - tam, kde návratnost je mnohanásobná." 15

Samostatnou kapitolou by přitom bylo pojednání o úloze zřizovatele, v jehož zájmu by přirozeně měl být tlak na efektivní hospodaření školy a zároveň na to, aby služby, které má poskytovat, realizovala efektivně a s ohledem na skutečné potřeby svých klientů (k čemuž je marketing nejlepším vodítkem).

V neposlední řadě je třeba konstatovat, že dle obecně uznávaných pojetí (např. Kotler, Keller, 1993) je marketing chápán jako nástroj managementu. Je proto nasnadě, že marketing lze aplikovat jen v prostředí fungujících řídících procesů, tedy tam, kde jsou pro jeho uplatnění učiněny všechny nezbytné předpoklady.

\section{Koncept marketingu základního uměleckého školství}

Za premisu tohoto příspěvku autor zvolil, a snad na předchozích řádcích i zdůvodnil, předpoklad žádoucnosti aplikace marketingu do základního uměleckého školství. Z toho vyrůstá i následující definice konceptu marketingu základního uměleckého školství, který autor chápe jako speciální oborovou aplikaci marketingu školství ovlivněnou arts marketingem.

Při formulování konceptu marketingu základního uměleckého školství je tak nutno zohlednit tři východiska:

- zásady marketingu školství,

- některé zásady a teorémy marketingu služeb a arts marketingu,

- specifika základního uměleckého školství.

Máme-li popsat vzájemnou souvztažnost jmenovaných disciplín, je třeba říct, že marketing školství vyrostl ponejvíce na konceptu marketingu služeb; produkty činnosti školy jsou totiž klasickou službou (byt' veřejného charakteru), poskytovanou předem známému okruhu příjemců, kteří ji prrijímají na určitém místě, $\mathrm{v}$ určitém čase a př́jemce si dokonce může $\mathrm{v}$ jisté míře vybrat poskytovatele, tedy školu, podle jejího renomé, výsledků práce či celkového působení instituce navenek (srov. se zmiňovanou rezistencí škol vůči marketingu). Specifikem je ovšem $\mathrm{v}$ tomto př́padě to, že tato služba je ponejvíce poskytována bezplatně a její spotřeba je v některých př́ípadech (např. povinná základní školní docházka) vynucená; to jsou však obecná specifika služeb produkovaných veřejným

15 DRUCKER, Peter. Řizení neziskových organizací: praxe a principy. 1. vyd. Praha: MANAGEMENT PRESS, 1994, s. 122. 
sektorem, spolu s jejich dalšími rysy - například že jsou poskytovány ve veřejném zájmu nebo že by měly zajišstovat rozvoj lidského potenciálu. ${ }^{16}$

Z marketingu služeb přejímá marketing školství taktéž charakteristiky služeb, jimiž jsou, jak známo, nehmatatelnost, nemožnost službu předem vyzkoušet, proměnlivost kvality, nepřenositelnost $\mathrm{v}$ čase a prostoru a významná závislost na lidském faktoru. ${ }^{17}$

Pokud bychom měli označit některou z tezí marketingu školství za klíčovou pro ustavení konceptu marketingu základního uměleckého školství, byly by to především některé zásady jeho klasické koncepce. Ta považuje studenty za zákazníky školy a tvrdí, že jejich přání a potřeby týkající se jejich vzdělání musí být školou uspokojeny co nejlépe. ${ }^{18}$ Toto pojetí je klíčové vzhledem k charakteru základních uměleckých škol, které na rozdíl od většiny ostatních školských institucí poskytují vzdělávání za úplatu. Opř́ít se lze také o konstatování Petera Druckera, že ,strategie neziskových institucí by méla začínat vždy u zákazníka. “19

Arts marketing je souhrnným označením pro marketing aplikovaný do podmínek umění a kulturního dědictví. Jeho posláním je tak samozřejmě nacházet a podněcovat poptávku po těchto specifických oborech lidské činnosti a jejich produkty - at' už produktem rozumíme umělecké dílo nebo třeba muzejní expozici. ${ }^{20}$ Základní umělecké školy, jak jsme uvedli výše, lze postavit po bok kulturních organizací $\mathrm{v}$ tom smyslu, že i jejich posláním by měla být předávání a reprodukce kulturních a uměleckých hodnot. $Z$ arts marketingu by si proto koncept marketingu základního uměleckého školství měl vzít pohled na kulturně-umělecké hodnoty, předávané cestou uměleckého vzdělávání, jako na předmět zájmu subjektů trhu, veřejného i neziskového sektoru - tedy jako na cosi, co zasahuje celou společnost.

Máme-li tedy vyslovit již několikrát avizovaný koncept marketingu základního uměleckého školství, mohl by znít s ohledem ke shora uvedenému takto:

Marketing základního uméleckého školstvi je speciálni oborovou aplikaci marketingu školství, jejímž posláním je působit ve vztahu mezi školou, jejím zákazníkem a veřejností tak, že škola bude s ohledem na potřeby zákazníka a veřejnou objednávku poskytovat nejen vzdělání v uměleckých disciplinách, ale bude taktéž sloužit jako médium reprodukce kulturně-uměleckých hodnot cestou přidané hodnoty $k$ poskytovaným službám.

16 BENČO, Jozef. Verejný sektor a verejné služby. 1. vyd. Kunovice: Evropský polytechnický institut, s.r.o., 2005, s. 37.

17 JANEČKOVÁ, Lidmila, VAŠTÍKOVÁ, Miroslava. Marketing služeb. 1. vyd. Praha: Grada Publishing, spol. s r.o., 2001, s. 13-22.

18 SVĚTLÍK, Jaroslav. Marketing školy. 1. vyd. Zlín: EKKA, 1996, s. 23.

19 DRUCKER, Peter. Řizení neziskových organizaci: praxe a principy. 1. vyd. Praha: MANAGEMENT PRESS, 1994, s. 92.

20 ČERNÁ, Jitka, JOHNOVÁ Radka et al. Arts marketing. 1. vyd. Praha: Vysoká škola ekonomická v Praze, 2007, s. 20. 


\section{Závěrem}

Ve společnosti v současné době existuje vnímání základních uměleckých škol coby tradičních vzdělávacích institucí a vysoce kvalitních poskytovatelů uměleckého vzdělání. Zároveň i nadále méně poučená část veřejnosti zaměňuje základní umělecké školy za zájmové vzdělávání nebo různé aktivity typu výuky uměleckých disciplín na bázi kroužků. Při výběru poskytovatele uměleckého vzdělání přitom často nerozhoduje pouze kvalitativní měřítko, ale taktéž otázky spojené s charakterem nabízené služby, cenou, místem poskytování nebo způsobem, jakými o sobě potenciální poskytovatelé informují. Rozhodují zde tedy kategorie, které marketing označuje za klíčové a staví na nich. Soukromí poskytovatelé služeb spojených s uměleckým vzděláváním si velmi dobře uvědomují preference spotřebitele, $v$ tomto př́ípadě rodiče potenciálního žáka. Proto si také umění marketingu osvojily s pružností, která je soukromému sektoru obecně vlastnější, než veřejnému.

Pokud bychom chtěli konkrétněji vyjádřit úlohu základních uměleckých škol ve společnosti, spatřujeme především tři zásadní oblasti, v nichž základní umělecké školy znamenají prínos:

a) rozvíjení talentu mládeže a její kultivace,

b) aktivní a smysluplné trávení volného času,

c) zprostředkování a udržování hodnot spočívajících v klasických uměních.

Všechny tři body by se docela jistě staly dobrým základem často chybějící definice poslání základních uměleckých škol, jak jsme o tom hovořili výše.

Máme-li se nyní navrátit na úvod tohoto př́spěvku, kde jsme se ptali po společenské objednávce směrem k základnímu uměleckému vzdělávání, mohla by znít právě ve smyslu shora uvedených bodů a) - c).

Ztotožní-li se s touto objednávkou i samy základní umělecké školy, bude jim marketing dobrým pomocníkem $\mathrm{v}$ jejím plnění. A protože soukromé základní umělecké školy se s touto objednávkou ztotožnily již dávno, máme na mysli samožrejmě veřejné základní umělecké školy.

Michal Šeba (michal.seba@uhk.cz), Katedra českého jazyka a literatury, Pedagogická fakulta, Univerzita Hradec Králové, CZ.

\section{ABSTRACT A QUESTION OF MARKETING FOR PRIMARY SCHOOLS OF ARTS}

This text deals with the question of marketing and its application in conditions of primary schools of arts. The subject of the text is mainly to describe the context of primary schools of arts, describe their position in the market of educational services and contribute to substantiate the need for marketing in terms of in these educational institutions. Marketing for primary schools of arts is described in context of the other disciplines of marketing. The text also describes the most common problems with its application. Furthermore, the text defines concept of marketing of primary schools of arts. Finally text also discusses public requisition in the area of primary schools of arts. 


\section{Key words}

marketing for primary school of arts, non goverment organizations, public sector, education, market of educational services

\section{Bilbliography}

BENČO, Jozef. Verejný sektor a verejné služby. 1. vyd. Kunovice: Evropský polytechnický institut, s.r.o., 2005.

ČERNÁ, Jitka, JOHNOVÁ Radka et al. Arts marketing. 1. vyd. Praha: Vysoká škola ekonomická v Praze, 2007.

DRUCKER, Peter. Řizeni neziskových organizací: praxe a principy. 1. vyd. Praha: MANAGEMENT PRESS, 1994.

JAKUBÍKOVÁ, Dagmar. Aplikace marketingu ve školství. 1. vyd. Plzeň: Vydavatelství Západočeské univerzity, 1998.

JANEČKOVÁ, Lidmila, VAŠTÍKOVÁ, Miroslava. Marketing služeb. 1. vyd. Praha: Grada Publishing, spol. s r.o., 2001.

KOLÍNKOVÁ, Libuše. Ředitel marketérem: aneb Marketing v českém školství. Strategie.cz [online]. 26. května 2008, [cit. 2015-07-14]. Dostupný z WWW: <http://www.strategie.cz/scripts/ detail.php?id=360688>.

Ministerstvo spravedlnosti ČR. Zákony a stanoviska - Texty zákonů: Nový občanský zákoník [online]. 2013 - 2015 [cit. 2015-07-01]. Dostupné z: <http://obcanskyzakonik.justice.cz/texty-za$\mathrm{konu} / \mathrm{s}$.

PESTOFF, Victor A. Reforming Social Services in Central Eastern Europe and Eleven Nation Overview. In: Sborník CRYF, Krakov 1995.

POL, Milan. Škola v proměnách. 1. vyd. Brno: Masarykova univerzita, 2007.

PRŮCHA, Jan. Pedagogická encyklopedie. 1. vyd. Praha: Portál, 2009.

Rámcový vzdělávací program pro základní umělecké vzdělávání. 1. vydání. [online]. Praha: Výzkumný ústav pedagogický, 2010. 63 s. [cit. 2015-07-01]. Dostupné z WWW: <http://www. vuppraha.cz/wp-content/uploads/2009/12/PRM_RVPZUV_NAWEB.pdf $>$.

SVĚTLÍK, Jaroslav. Marketing školy. 1. vyd. Zlín: EKKA, 1996.

ŠEBA, Michal. Aplikace marketingové komunikace v základním uměleckém školství. Brno, 2010. Diplomová práce. Masarykova univerzita. 